\title{
Glucagon-like Peptide-1 Stimulates Luteinizing Hormone-releasing Hormone Secretion in a Rodent Hypothalamic Neuronal Cell Line
}

\author{
Sarah A. Beak, ${ }^{\star}$ Melanie M. Heath, ${ }^{\star}$ Caroline J. Small,, ${ }^{\star}$ David G.A. Morgan, ${ }^{\star}$ Mohammad A. Ghatei, ${ }^{\star}$ Amanda D. Taylor, ${ }^{\ddagger}$ \\ Julia C. Buckingham, ${ }^{\ddagger}$ Stephen R. Bloom, ${ }^{*}$ and David M. Smith* \\ *Division of Endocrinology and Metabolic Medicine, Department of Medicine, Royal Postgraduate Medical School, Hammersmith \\ Hospital, London W12 ONN, United Kingdom; and ${ }^{\ddagger}$ Department of Pharmacology, Charing Cross and Westminster Medical School, \\ London W6 8RF, United Kingdom
}

\begin{abstract}
To examine the influence of the putative satiety factor (GLP-1) on the hypothalamo-pituitary-gonadal axis, we used $\mathrm{GT}_{1}-7$ cells as a model of neuronal luteinizing hormonereleasing hormone (LHRH) release. GLP-1 caused a concentration-dependent increase in LHRH release from $\mathrm{GT}_{1-7}$ cells. Specific, saturable GLP-1 binding sites were demonstrated on these cells. The binding of $\left[{ }^{125} \mathrm{I}\right] \mathrm{GLP}-1$ was timedependent and consistent with a single binding site $\left(K_{\mathrm{d}}=\right.$ $0.07 \pm 0.016 \mathrm{nM}$; binding capacity $=160 \pm 11 \mathrm{fmol} / \mathrm{mg}$ protein). The specific GLP-1 receptor agonists, exendin-3 and exendin-4, also showed high affinity $\left(K_{\mathrm{i}}=0.3 \pm 0.05\right.$ and $0.32 \pm 0.06 \mathrm{nM}$, respectively) as did the antagonist exen$\operatorname{din}-(9-39)\left(K_{\mathrm{i}}=0.98 \pm 0.24 \mathrm{nM}\right)$. At concentrations that increased LHRH release, GLP-1 $(0.5-10 \mathrm{nM})$ also caused an increase in intracellular cAMP in $\mathrm{GT}_{1}-7$ cells (10 nM GLP-1: $7.66 \pm 0.4$ vs. control: $0.23 \pm 0.02 \mathrm{nmol} / \mathrm{mg}$ protein; $P<0.001)$. Intracerebroventricular injection of GLP-1 at a single concentration $(10 \mu \mathrm{g})$ produced a prompt increase in the plasma luteinizing hormone concentration in male rats (GLP-1: $1.09 \pm 0.11$ vs. saline: $0.69 \pm 0.06 \mathrm{ng} / \mathrm{ml} ; P<0.005$ ). GLP-1 levels in the hypothalami of 48-h-fasted male rats showed a decrease, indicating a possible association of the satiety factor with the low luteinizing hormone levels in animals with a negative energy balance. (J. Clin. Invest. 1998. 101:1334-1341.) Key words: receptors • rat-Wistar • peptidespharmacology $\bullet$ cell line $\bullet$ hypothalamus
\end{abstract}

\section{Introduction}

Glucagon-like peptide-1(7-36) amide (GLP-1) $)^{1}$ is processed from proglucagon in intestinal L cells (1), and is a member of

Address correspondence to David M. Smith, Division of Endocrinology and Metabolic Medicine, Department of Medicine, Royal Postgraduate Medical School, Hammersmith Hospital, London W6 8RF, United Kingdom. Phone: +44-181-383-4552; FAX: +44-181-383-3142; E-mail: dsmith@rpms.ac.uk

Received for publication 12 May 1997 and accepted in revised form 12 January 1998

1. Abbreviations used in this paper: aCSF, artificial cerebrospinal fluid; $\mathrm{B}_{\max }$, binding capacity; $\mathrm{Bq}$, becquerels; CNS, central nervous system; GLP-1, glucagon-like peptide-1; LH, luteinizing hormone; LHRH, luteinizing hormone-releasing hormone.

J. Clin. Invest.

(C) The American Society for Clinical Investigation, Inc. 0021-9738/98/03/1334/08 \$2.00

Volume 101, Number 6, March 1998, 1334-1341

http://www.jci.org the structurally related glucagon/secretin family of peptides. Furthering its well-documented roles in the periphery, more recent studies indicate a role for GLP-1 as a brain neuropeptide. The processing of proglucagon in the central nervous system (CNS; references 2-4) resembles that in the intestine (5), with GLP-1 as a major biologically active product. Immunocytochemical studies have demonstrated the presence of GLP-1 immunoreactive cell bodies in the nucleus of the solitary tract and the medullary reticular nucleus in the rat brain (6). The peptide has also been identified in nerve fibers in medial hypothalamic structures including the hypothalamic paraventricular nucleus and the periventricular strata $(4,6,7)$. The presence of GLP-1 in the synaptosome fraction of the hypothalamus, its calcium-dependent release from hypothalamic tissue slices by potassium stimulation (4), and the existence of specific receptors for GLP-1 in the CNS (8) support a putative neurotransmitter or neuromodulatory role for this peptide.

The GLP-1 receptor belongs to a distinct subclass of the G-protein-coupled receptor family that includes receptors for glucagon, secretin, vasoactive intestinal peptide, growth hormone-releasing hormone, parathyroid hormone, and calcitonin (for review see reference 9). Specific CNS GLP-1 receptors have been demonstrated in this laboratory and elsewhere, in hypothalamic and thalamic nuclei, in the brain stem, and in the pituitary gland (7, 10-12). Moreover, after elucidating the GLP-1 receptor nucleotide sequence (13), in situ hybridization studies demonstrated sites of GLP-1 receptor synthesis in both neurons and glia of the hypothalamus, thalamus, hippocampus, primary olfactory cortex, choroid plexus, and pituitary gland (14). More detailed studies of the distribution of GLP-1 receptor mRNA in the hypothalamus revealed dense accumulation of labeled cells in the supraoptic, paraventricular, and arcuate nuclei. Additional labeled cells were also detected in medial and lateral preoptic areas, the periventricular nucleus, the ventral division of the bed of stria terminalis, the lateral hypothalamus, and the dorsomedial nucleus (15).

GLP-1 immunoreactivity is widely distributed and colocalized with specific GLP-1 binding sites in regions of the CNS associated with the control of various endocrine and behavioral responses (16), evidence that supports a role for GLP-1 as a modulator of neuroendocrine and/or autonomic outflow. We and others have demonstrated that GLP-1 inhibits food (10, $17,18)$ and water (18) intake when given intracerebroventricularly to rats. In addition, we have identified a potential role for GLP-1 in the regulation of thyrotropin release, which appears to involve direct actions of the peptide on the anterior pituitary gland (19). Taking into consideration these findings, in particular its role as a known satiety factor in the CNS $(10,17$, 18), it is possible that GLP-1, like several other hypothalamic neuropeptides $(20,21)$, acts as a metabolic signal to the reproductive system. In the present study we have primarily used the luteinizing hormone-releasing hormone (LHRH)-secret- 
ing hypothalamic cell line $\mathrm{GT}_{1}-7$ to examine the direct effects and mechanism of action of GLP-1 on LHRH release. We also examined the effect of intracerebroventricular injection of GLP-1 on LH release in vivo in male rats. To investigate a possible role for changes of hypothalamic GLP-1 content in the reduction of $\mathrm{LH}$ release observed in negative energy balance, we determined the effect of a 48-h fast and refeeding on hypothalamic GLP-1 content.

\section{Methods}

Materials. GLP-1 and the exendin peptides were synthesized using an automated peptide synthesizer (model 396 MPS; Advanced Chemtech Inc., Louisville, KY) and checked for correct molecular weight by mass spectroscopy. $\mathrm{Na}^{125} \mathrm{I}$ was supplied by Amersham International (Little Chalfont, United Kingdom). All tissue culture materials were supplied by Life Technologies (Paisley, United Kingdom), and all other reagents by Merck (Poole, United Kingdom) or Sigma Chemical Co. (Poole, United Kingdom).

$G T_{1}-7$ cell culture and membrane preparations. The immortalized hypothalamic LHRH-producing neurone subclone $\mathrm{GT}_{1}-7$ cells, which are derived from transgenic mice expressing a hybrid gene composed of the $5^{\prime}$ flanking region of the rat $L H R H$ gene linked to cDNA encoding the SV40 T antigen (22), were grown in $175-\mathrm{ml}$ plastic culture flasks. They were maintained at $37^{\circ} \mathrm{C}$ in $6 \% \mathrm{CO}_{2}$ in DME with $4.5 \mathrm{~g} /$ liter glucose, $10 \% \mathrm{FBS}$, penicillin $(100 \mathrm{IU} / \mathrm{ml})$, and streptomycin $(100 \mu \mathrm{g} / \mathrm{ml})$. Culture medium GLP-1 levels were measured by RIA (23) and were found to be below the detection limit of the assay ( $0.5 \mathrm{fmol} /$ tube with $95 \%$ confidence). To prepare membranes, cells (10-12 confluent flasks) were recovered by scraping cells into $20 \mathrm{ml}$ homogenization buffer (50 mM Hepes, $\mathrm{pH} 7.4$, containing $0.25 \mathrm{M}$ sucrose, $10 \mu \mathrm{g} / \mathrm{ml}$ soybean trypsin inhibitor, $0.5 \mu \mathrm{g} / \mathrm{ml}$ pepstatin, leupeptin and antipain, $0.1 \mathrm{mg} / \mathrm{ml}$ benzamidine, $0.1 \mathrm{mg} / \mathrm{ml}$ bacitracin and $30 \mu \mathrm{g} / \mathrm{ml}$ aprotinin $)$. Subsequent homogenization $(6 \times 30 \mathrm{~s})$ using an UltraTurrax homogenizer (Merck) resulted in cell breakdown, which was verified by microscopic examination. The homogenate was centrifuged at $1,000 \mathrm{~g}$ for $10 \mathrm{~min}$ at $4^{\circ} \mathrm{C}$, and the resulting supernatant was collected and centrifuged at $100,000 \mathrm{~g}$ for $1 \mathrm{~h}$ at $4^{\circ} \mathrm{C}$. The pellet was resuspended in $\sim 5 \mathrm{ml}$ of homogenization buffer without sucrose using a hand-held glass Teflon homogenizer (Merck). Protein concentration was measured by the Biuret method (24), and aliquoted membranes $(3 \mathrm{mg} / \mathrm{ml})$ were stored at $-80^{\circ} \mathrm{C}$.

Secretion experiments. $\mathrm{GT}_{1}-7$ cells were plated on poly-L-lysinecoated 24-well plates. After growing for 2-3 d, cells were washed twice in DME with $4.5 \mathrm{~g} /$ liter glucose, penicillin (100 IU/ml), streptomycin $(100 \mu \mathrm{g} / \mathrm{ml})$, and $0.1 \%$ BSA. The cells were then preincubated for $2 \mathrm{~h}$ in serum-free medium. Thereafter, the medium was discarded, and the cells were incubated in $500 \mu \mathrm{l}$ of medium plus the appropriate test substance (GLP-1, $0.01-100 \mathrm{nM}$ or $56 \mathrm{mM} \mathrm{KCl}$ ) for $60 \mathrm{~min}$. At the end of the incubation period, medium was removed and frozen at $-20^{\circ} \mathrm{C}$. Culture medium LHRH levels were measured using RIA (reagents and methods provided by Dr. H.M. Fraser, Medical Research Council Reproductive Biology Unit, Edinburgh, Scotland). Protein levels from each well were calculated using the Bio-Rad protein assay (25), and LHRH release was expressed per milligram of protein.

GLP-1-binding studies. GLP-1-binding studies were essentially carried out as previously described (19). In brief, GLP-1 was labeled with $\mathrm{Na}^{125} \mathrm{I}$ by the chloramine-T method, and the monoiodinated peptide was purified by high-performance liquid chromatography as described previously (19). The specific activity of the label, determined by RIA (23), was $50 \pm 4.2$ becquerels $(\mathrm{Bq}) / \mathrm{fmol}(n=6) . \mathrm{GT}_{1}-7$ cell membranes $(50 \mu \mathrm{g})$ were incubated with $\left[{ }^{125} \mathrm{I}\right] \mathrm{GLP}-1(750 \mathrm{~Bq}, 30$ $\mathrm{pM}$ ) for $90 \mathrm{~min}$ at $20^{\circ} \mathrm{C}$ in a final assay volume of $0.5 \mathrm{ml}$. Specific binding was calculated as the difference between the amount of [ $\left.{ }^{125} \mathrm{I}\right] \mathrm{GLP}-1$ bound in the absence (total) and presence (nonspecific) of $200 \mathrm{nM}$ unlabeled peptide. Dissociation was measured at $20^{\circ} \mathrm{C}$ and $37^{\circ} \mathrm{C}$ after adding $1 \mu \mathrm{M}$ (final concentration) of unlabeled GLP-1 and $500 \mu \mathrm{M}$ guanosine $5^{\prime}$-triphosphate (GTP) to membranes, and $\left.{ }^{125} \mathrm{I}\right] \mathrm{GLP}-1(30 \mathrm{pM})$ in equilibrium after a 90 -min incubation. Equilibrium saturation experiments were performed using $25 \mu \mathrm{g}$ of membrane protein and label from 40-1,600 pM (500-20,000 Bq/assay) in an assay volume of $0.25 \mathrm{ml}$. In equilibrium competition experiments, the concentration of unlabeled peptide was from 0 to $200 \mathrm{nM}$. Binding data were analyzed by nonlinear regression using the Receptor Fit programme (Lundon Software, Cleveland, $\mathrm{OH}$ ) to calculate the dissociation constant $\left(K_{\mathrm{d}}\right)$, the absolute inhibition constant $\left(K_{\mathrm{i}}\right)$, and the concentration of binding sites $\left(\mathrm{B}_{\max }\right)$. The integrity of the label after binding was determined by $10 \%$ trichloroacetic acid precipitation. Degradation of the label was always $<10 \%$ regardless of the time of incubation (data not shown).

Determination of cAMP generation. $\mathrm{GT}_{1}-7$ cells were plated onto poly-L-lysine-coated 24-well plates, as described above. After growing for 2-3 d, cells were again washed twice in serum-free DME and preincubated for $2 \mathrm{~h}$. Thereafter, the medium was discarded, and the cells were incubated for $10 \mathrm{~min}$ in DME containing $2 \mathrm{mM} 3$-isobutyl1-methyl-xanthine alone, or with GLP-1 (0.01 nM-10 nM), forskolin $(10 \mu \mathrm{M}, 100 \mu \mathrm{M})$, or GLP-1 (1 nM) plus exendin-(9-39) (1-100 nM). The cells were washed once with $500 \mu \mathrm{l}$ of PBS and extracted in 500 $\mu \mathrm{l}$ of $75 \%$ ethanol containing $16 \mathrm{mM} \mathrm{HCl}$, at $-20^{\circ} \mathrm{C}$ overnight. Samples were dried by rotary evaporation, and cAMP concentrations were assessed using a cAMP radioimmunoassay kit (Du Pont, Stevenage, United Kingdom). Protein levels were calculated from representative wells on the plates using the Bio-Rad protein assay (25), and cAMP levels were expressed per milligram of protein.

Cytoplasmic $\mathrm{Ca}^{2+}$ measurements. Cytoplasmic calcium was measured in $\mathrm{GT}_{1}-7$ cell suspensions. $\mathrm{GT}_{1}-7$ cells were cultured to $80-90 \%$ confluence in plastic $175-\mathrm{ml}$ flasks as described above. Cells were then loaded with fura- 2 at $37^{\circ} \mathrm{C}$ by incubation in $5 \mu \mathrm{M}$ fura-2-AM (Novabiochem, Nottingham, United Kingdom) for $30 \mathrm{~min}$. The fura2-AM containing extracellular medium was subsequently removed, and the cells were scraped into $20 \mathrm{ml}$ of assay buffer ( $10 \mathrm{mM}$ Hepes, pH 7.2, containing $140 \mathrm{mM} \mathrm{NaCl}, 2.8 \mathrm{mM} \mathrm{KCl}, 2 \mathrm{mM} \mathrm{MgCl}_{2}, 3 \mathrm{mM}$ $\mathrm{CaCl}_{2}$, and $6 \mathrm{mM}$ glucose). Spectrofluorometric analysis of $\mathrm{Ca}^{2+}$ was conducted at $22^{\circ} \mathrm{C}$ as described previously (27) using a Shimadzu RF5001PC (Shimadzu Experimental Supplies, Kyoto, Japan), and analysis of the ratio between fluorescence was measured at 340 and $380 \mathrm{~nm}$. GLP-1 (up to $5 \mu \mathrm{M})$ was compared with $\mathrm{K}^{+}(20 \mathrm{mM})$ and histamine $(100 \mu \mathrm{M})$ as positive controls.

Investigation of the effect of fasting on rat hypothalamic GLP-1 content. Adult male Wistar rats (200-220 g) were maintained in groups of five animals per cage under controlled temperature (21$23^{\circ} \mathrm{C}$ ) and light ( $11 \mathrm{~h}$ of light, $13 \mathrm{~h}$ of darkness) with ad libitum access to chow and water. At the beginning of the study the animals were divided into three groups $(n=15)$. Group 1 animals were fasted for $48 \mathrm{~h}$, group 2 animals were fasted for $48 \mathrm{~h}$ and then refed for $12 \mathrm{~h}$ in the dark (feeding) phase, and group 3 animals acted as control with ad libitum access to chow. All animals had ad libitum access to water. The rats were killed by decapitation, followed by immediate microdissection of whole hypothalami, which were frozen in liquid nitrogen. The tissue removed was bordered rostrally by the anterior edge of the optic chiasma, laterally by the hypothalamic fissures, and caudally by the mamillary bodies. The ventral border of the dorsal extent of the cut was at a depth of no more than $2 \mathrm{~mm}$. Tissue extraction was carried out as previously described (4). In brief, each hypothalamus was placed into $500 \mu \mathrm{l}$ of $0.5 \mathrm{M}$ acetic acid at $100^{\circ} \mathrm{C}$ for $10 \mathrm{~min}$. The extract was stored at $-20^{\circ} \mathrm{C}$. GLP-1 levels were measured by RIA (23). Protein concentration in the extract was calculated using the Bio-Rad protein assay (25), and GLP-1 content was expressed as fmol per mg of extracted protein.

In vivo LH studies. Adult male Wistar rats (200-220 g) were maintained as above. Rats were anaesthetized, and stainless steel guide cannulae were implanted into the third cerebral ventricle as previously described $(10,28)$. After a 7 -d recovery period, rats failing to exhibit a drinking response to intracerebroventricular injection of 
angiotensin II $(150 \mathrm{ng}$ in $10 \mu \mathrm{l})$ were excluded $(<10 \%)$. Animals displaying a positive drinking response were sham-injected before the study, and weighed and handled daily.

GLP-1 was dissolved in $0.9 \%$ saline and administered intracerebroventricularly as previously described (28). Each study involved an injection of $10 \mu \mathrm{l}$ of GLP-1 (10 $\mu \mathrm{g})$ or saline. After intracerebroventricular injection, rats were returned to their cages and decapitated after 5 min. Trunk blood was collected in plastic lithium heparin tubes containing $0.6 \mathrm{mg}$ aprotinin. Plasma was separated by centrifugation, frozen immediately on dry ice, and stored at $-20^{\circ} \mathrm{C}$. Plasma LH was measured using the reagents and methods provided by the NIDDK and the National Hormone and Pituitary Program (Dr. A. Parlow, Harbor-University of California-Los Angeles Medical Center, Los Angeles, CA). A double antibody separation system was employed, which used a goat anti-rabbit solid-phase antibody (Kabi AB, Stockholm, Sweden) and 0.1\% Triton-X 100. Results were calculated in terms of NIDDK standard preparation (NIDDK rat LH-RP-3).

Static incubation of whole hypothalami. The static incubation system used was a modification of the method previously described (29). Adult male Wistar rats (200-220 g) were maintained in groups of five animals per cage as above. On the day of the study, the rats were killed by stunning and decapitation, followed by immediate microdissection of whole hypothalami as described above. The tissue blocks ( $<35 \mathrm{mg}$ wet wt each) were transferred to individual tubes containing $1 \mathrm{ml}$ artificial cerebrospinal fluid (aCSF; $20 \mathrm{mM} \mathrm{NaHCO} 3,126 \mathrm{mM}$ $\mathrm{NaCl}, 0.09 \mathrm{mM} \mathrm{Na}_{2} \mathrm{HPO}_{4}, 6 \mathrm{mM} \mathrm{KCl}, 1.4 \mathrm{mM} \mathrm{Ca} 2 \mathrm{Cl}, 0.09 \mathrm{mM}$ $\mathrm{MgSO}_{4}, 1 \mathrm{mM}$ glucose, $0.18 \mathrm{mg} / \mathrm{ml}$ ascorbic acid, and $100 \mu \mathrm{g} / \mathrm{ml}$ aprotinin). The tubes were placed on a shaking platform in a water bath (maintained at $37^{\circ} \mathrm{C}$ in $95 \% \mathrm{O}_{2}, 5 \% \mathrm{CO}_{2}$ ) and preincubated for 60 $\mathrm{min}$. The hypothalami were then incubated for $30 \mathrm{~min}$ in $0.5 \mathrm{ml}$ fresh aCSF (basal release) before being challenged with $1 \mu \mathrm{M}$ GLP-1 in $0.5 \mathrm{ml}$ fresh aCSF for $60 \mathrm{~min}$. Finally, the viability of the tissue was verified by a 30-min exposure to $56 \mathrm{mM} \mathrm{KCl}$. Isotonicity was maintained by substituting $\mathrm{Na}^{+}$for $\mathrm{K}^{+}$. LHRH concentrations were measured by RIA as above and expressed per milligram wet weight tissue per $h$.

Statistics. Results are shown as mean values $\pm \mathrm{SE}$. For the $\mathrm{GT}_{1}-7$ cell cAMP, LHRH, and hypothalamic GLP-1 content assays, data were compared by repeated measures ANOVA with subsequent post hoc Tukey's tests (Systat, Evanston, IL) between control and experimental groups, with $P<0.05$ considered to be statistically significant. For the LH and whole hypothalami LHRH assays, data were compared by unpaired and paired Student's $t$ test, respectively, with $P<$ 0.05 considered to be statistically significant. For binding data, analysis of one-site vs. two-site competition curves was by F-test, with two component fits considered significant at $P<0.05$.

\section{Results}

Effect of GLP-1 on LHRH release in $G T_{1}-7$ cells. The effect of GLP-1 on LHRH release from $\mathrm{GT}_{1}-7$ cells in static culture was examined (Fig. 1). Exposure of the cells to GLP-1 for 60 min resulted in dose-dependent stimulation of $\mathrm{LHRH}$ release with a significant effect of dose vs. response $[\mathrm{F}(7,65)=93.68$; $P<0.0001$ ]. At concentrations of $0.5,1.0$, and $10 \mathrm{nM}$, GLP-1 produced pronounced LHRH responses that were significantly increased when compared with basal levels. Basal release was $325 \pm 17 \mathrm{fmol} / \mathrm{mg}$ protein, and GLP-1 (10 nM) increased this to a maximum of $242 \%$ of basal $(787 \pm 45 \mathrm{fmol} / \mathrm{mg}$ protein; $P<0.0001, n=4)$. Control cells were exposed to $56 \mathrm{mM}$ $\mathrm{KCl} ; \mathrm{K}^{+}$stimulated $\mathrm{LHRH}$ release to $1467 \pm 65 \mathrm{fmol} / \mathrm{mg}$ protein $(P<0.0001, n=4)$. The $\mathrm{EC}_{50}$ for GLP-1-stimulated LHRH release from $\mathrm{GT}_{1}-7$ cells was calculated to be $0.28 \mathrm{nM}$.

Characterization of $\left[{ }^{125} I\right] G L P-1$ binding in $G T_{1}-7$ cell membranes. [ $\left.{ }^{125} \mathrm{I}\right] \mathrm{GLP}-1(30 \mathrm{pM})$-specific binding to $50 \mu \mathrm{g}$ cell membranes for $90 \mathrm{~min}$ at $20^{\circ} \mathrm{C}$ represented $87.7 \pm 1.0 \%(n=$ 10 ) of the total radioactivity bound. Specific binding was time-

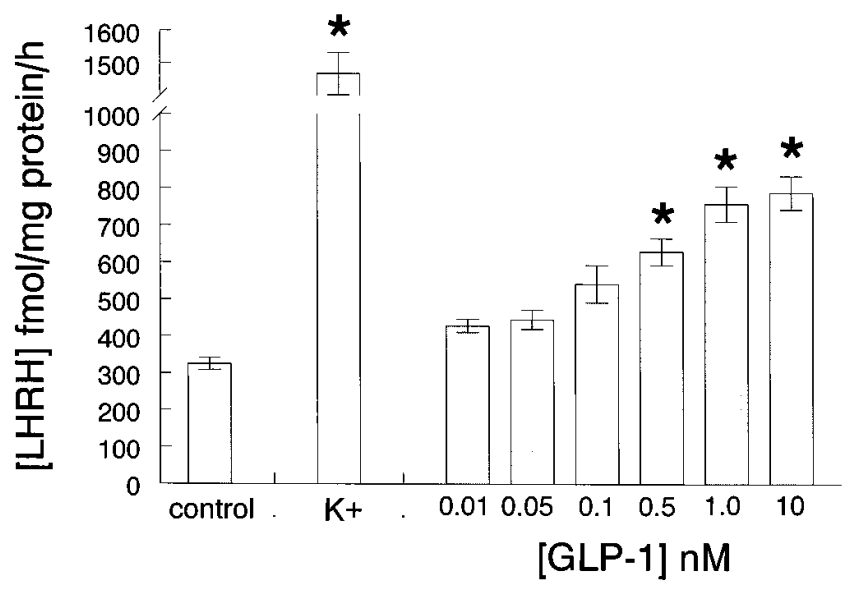

Figure 1. GLP-1 stimulation of basal LHRH secretion from GT1-7 cells. Culture medium LHRH levels were measured by RIA after 60 min of incubation in the presence of GLP-1 $(0.01-10 \mathrm{nM})$ or $56 \mathrm{mM}$ $\mathrm{KCl}$. Results are the mean $\pm \mathrm{SE}$ of four experiments performed in quadruplicate and expressed as fmoles of LHRH secreted per milligram of protein per h. $[\mathrm{F}(7,65)=93.68, P<0.0001]$. $\left({ }^{*} P<0.0001\right.$ vs. control).

(Fig. 2) and temperature- (data not shown) dependent. The association and dissociation time courses are shown in Fig. 2. Tracer-specific binding can be seen to reach steady-state by $\sim 90$ min. Very slight dissociation was observed upon addition of $1 \mu \mathrm{M}$ unlabeled GLP-1 to membranes in equilibrium with the label (data not shown). However, on addition of both $1 \mu \mathrm{M}$ unlabeled peptide and $500 \mu \mathrm{M}$ GTP, dissociation was $\sim 50 \%$ and $65 \%$ complete after $200 \mathrm{~min}$ at $20^{\circ} \mathrm{C}$ and $37^{\circ} \mathrm{C}$, respectively, suggesting involvement of guanine nucleotides and G-protein linkage of the receptor. Dissociation was more pro-

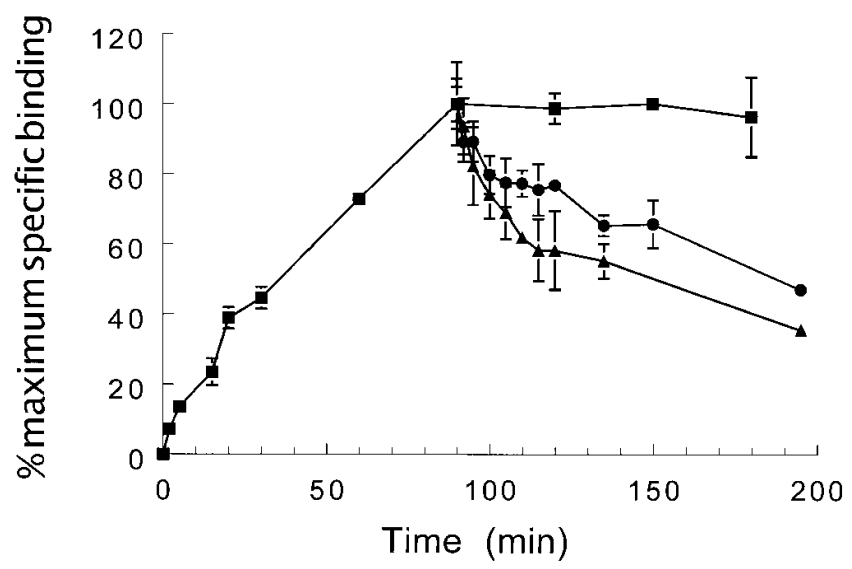

Figure 2. Kinetics of [ $\left.{ }^{125} \mathrm{I}\right] \mathrm{GLP}-1$ binding in GT1-7 cells. Association $\left(\boldsymbol{\square}, 20^{\circ} \mathrm{C}\right)$ and dissociation $\left(\bullet, 500 \mu \mathrm{M} \mathrm{GTP}\right.$ at $20^{\circ} \mathrm{C} ; \boldsymbol{\Delta}, 500 \mu \mathrm{M}$ GTP at $\left.37^{\circ} \mathrm{C}\right)$ of $\left[{ }^{125} \mathrm{I}\right] \mathrm{GLP}-1(30 \mathrm{pM})$ in $\mathrm{GT}_{1^{-}}-7$ cell membranes $(50 \mu \mathrm{g})$. All points are the mean $\pm \mathrm{SE}$ of triplicate assays in three separate experiments. Dissociation of [ $\left.{ }^{125} \mathrm{I}\right] \mathrm{GLP}-1$ in equilibrium was initiated at 90 min by adding unlabeled GLP-1 to a final concentration of $1 \mu \mathrm{M}$ and $500 \mu \mathrm{M} \mathrm{GTP}$ at $20^{\circ} \mathrm{C}$ and $37^{\circ} \mathrm{C}$. Bound and free were separated by rapid filtration under reduced pressure. Where no error bars are shown, they did not exceed the limits of the symbols. 




Figure 3. Equilibrium saturation analysis of $\left[{ }^{125} \mathrm{I}\right] \mathrm{GLP}-1$ binding. The effect of increasing concentrations of [ $\left.{ }^{125} \mathrm{I}\right] \mathrm{GLP}-1$ on specific binding in $\mathrm{GT}_{1}-7$ cell membranes $(25 \mu \mathrm{g})$ was determined. Results are expressed as the mean specific binding \pm SE of triplicate assays in three separate experiments. A Rosenthal plot is shown in inset, where $B$ is bound ligand and $F$ is free ligand. This figure is intended as a pictorial representation of the above data. Actual $B_{\max }$ values were calculated by nonlinear regression. nounced at $37^{\circ} \mathrm{C}$ than $20^{\circ} \mathrm{C}$, and appeared to be represented by two components, with a more rapid initial component. Specific $\left[{ }^{125} \mathrm{I}\right] \mathrm{GLP}-1$ binding at $20^{\circ} \mathrm{C}$ was proportional to membrane protein up to $200 \mu \mathrm{g}$ (data not shown). Consequently, for equilibrium competition binding studies, $50 \mu \mathrm{g}$ membrane protein were incubated with $30 \mathrm{pM}\left[{ }^{125} \mathrm{I}\right] \mathrm{GLP}-1$ plus unlabeled GLP-1 for $90 \mathrm{~min}$ at $20^{\circ} \mathrm{C}$.

Fig. 3 shows equilibrium saturation analysis that was carried out to establish saturation of binding and to determine the affinity and density of the sites. Analysis of the data indicated a single class of binding site with an estimated $K_{\mathrm{d}}$ of $0.07 \pm 0.016 \mathrm{nM}(n=3)$ and $\mathrm{a}_{\max }$ of $160 \pm 11 \mathrm{fmol} / \mathrm{mg}$ protein. Fig. 4 shows the results from equilibrium competition binding studies that were designed to determine the affinity and specificity of the binding of various GLP-1 receptor ligands to $\mathrm{GT}_{1}-7$ cell membranes. Competition curves were constructed using GLP-1, the exendin peptide agonists exendin-3 and exendin-4, and the truncated peptide antagonist exendin-(9-39). Tracerspecific binding was inhibited in a concentration-dependent manner by all four unlabeled peptides. The rank order of potency was as follows: GLP-1 $\left(K_{\mathrm{d}}=0.3 \pm 0.08 \mathrm{nM} ; n=3\right)=\mathrm{ex}-$
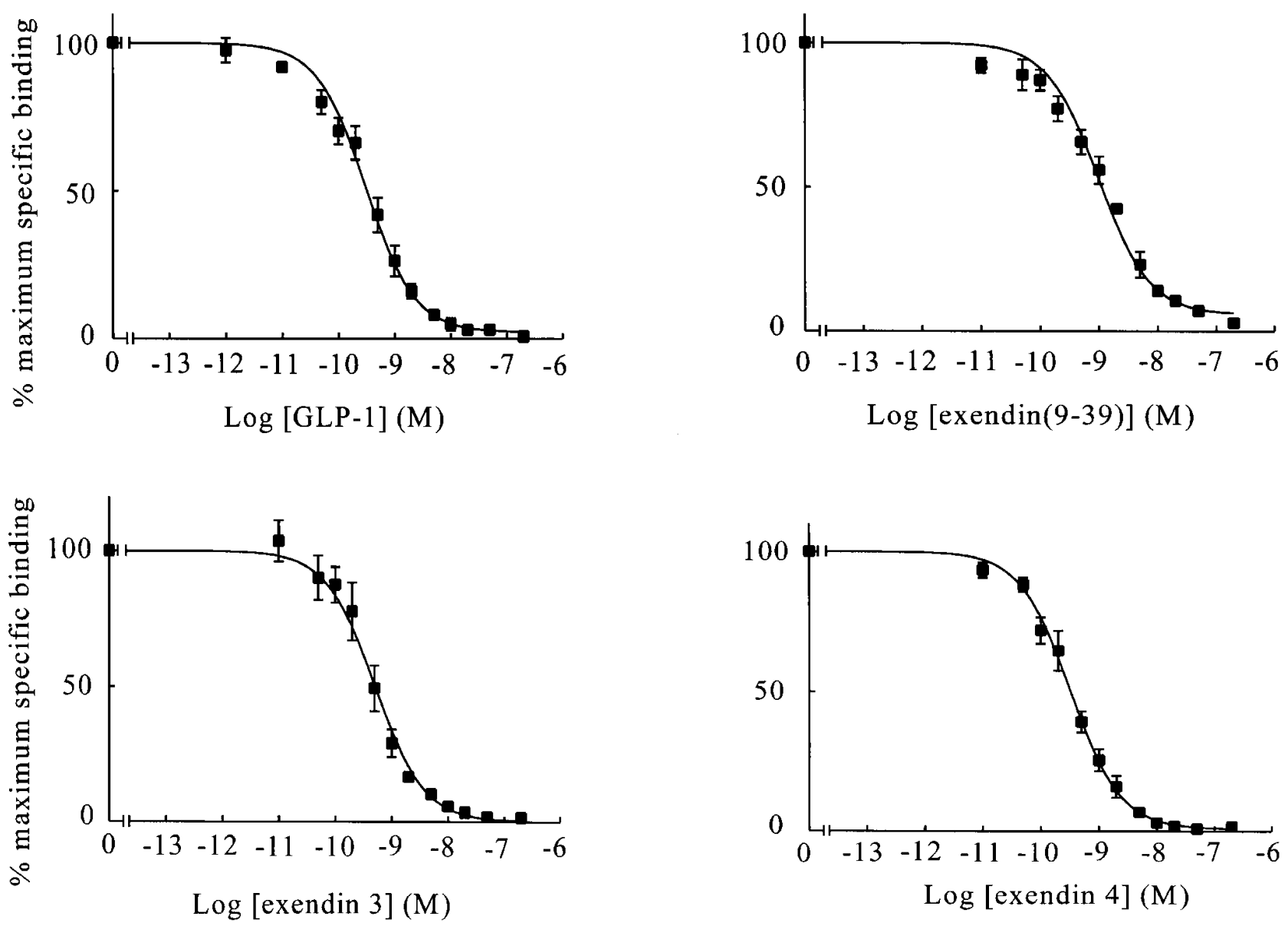

Figure 4. Equilibrium competition analysis of $\left[{ }^{125} \mathrm{I}\right] \mathrm{GLP}-1$ binding. Competition of $\left[{ }^{125} \mathrm{I}\right] \mathrm{GLP}-1(30 \mathrm{pM})$ binding in $\mathrm{GT}_{1}-7$ cell membranes $(50 \mu \mathrm{g})$ by GLP-1, exendin-3, exendin-(9-39) and exendin-4 was determined. Values are expressed as percentage of maximal specific binding, and are the mean of three separate experiments $\pm \mathrm{SE}$ with assays performed in triplicate. Where no error bars are shown, they did not exceed the limits of the symbols. 


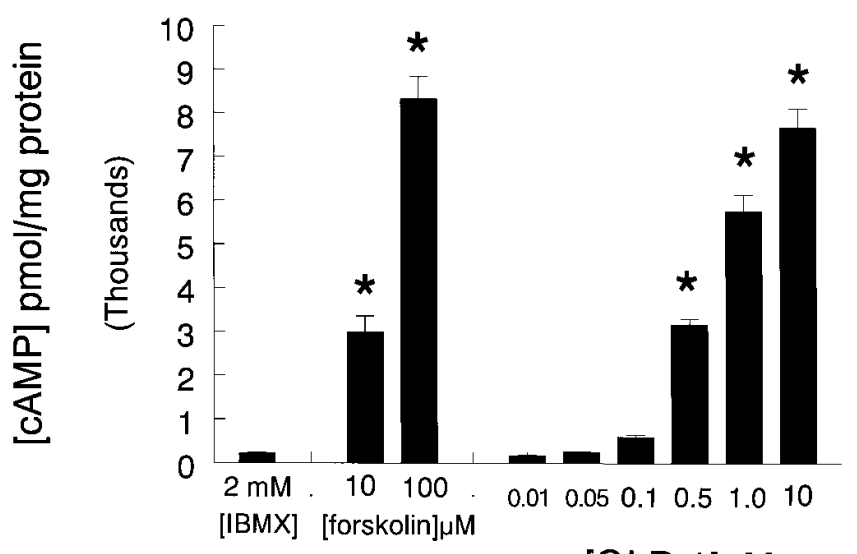

[GLP-1]nM

Figure 5. Effect of GLP-1 on cAMP production in GT1-7 cells. cAMP levels were determined after a 10-min incubation in medium containing $2 \mathrm{mM}$ IBMX alone or together with GLP-1 (0.01-10 nM) or forskolin $(10 \mu \mathrm{M}, 100 \mu \mathrm{M})$. Results are the mean \pm SE of four experiments performed in quadruplicate and expressed as pmol cAMP per milligram of protein. $[\mathrm{F}(8,63)=129.25 ; P<0.0001] .\left({ }^{*} P<0.0001\right.$ vs. control).

endin-3 $\left(K_{\mathrm{i}}=0.3 \pm 0.05 \mathrm{nM} ; n=3\right)$ exendin-4 $\left(K_{\mathrm{i}}=0.32 \pm 0.06\right.$ $\mathrm{nM} ; n=3)>$ exendin-(9-39) $\left(K_{\mathrm{i}}=0.98 \pm 0.24 \mathrm{nM} ; n=3\right)$.

The structurally related peptides - glucagon, pituitary adenylate cyclase-activating polypeptide, and vasoactive intestinal peptide - and the unrelated peptides-neuropeptide $\mathrm{Y}$ and calcitonin gene-related peptide-in concentrations up to $1 \mu \mathrm{M}$ were unable to inhibit [ $\left.{ }^{125} \mathrm{I}\right] \mathrm{GLP}-1$ binding, thereby establishing the specificity of binding (data not shown).

Effect of GLP-1 on cAMP production and intracellular $\mathrm{Ca}^{2+}$ levels in $\mathrm{GT}_{1}-7$ cells. Fig. 5 shows the effect of GLP-1 on intracellular cAMP levels. These studies were performed to determine whether the GLP-1 binding site on the $\mathrm{GT}_{1}-7$ cell membranes was functionally coupled to the adenylyl cyclase system. Basal production of cAMP in the unstimulated cells was $0.23 \pm 0.02 \mathrm{nmol} / \mathrm{mg}$ protein $(n=4)$. GLP-1 stimulated cAMP production in a concentration-dependent manner with a significant effect of dose vs. response $[\mathrm{F}(8,63)=129.35 ; P<$ $0.0001]$. Exposure to $0.5,1.0$, and $10 \mathrm{nM}$ GLP-1 produced significant increases in cAMP in comparison to basal levels. The greatest cAMP formation obtained (with $10 \mathrm{nM}$ of the peptide) was $7.76 \pm 0.4 \mathrm{nmol} / \mathrm{mg}$ protein, i.e., $3276 \%$ above the basal level $(P<0.0001, n=4)$. Control cells were exposed to 10 and $100 \mu \mathrm{M}$ forskolin, a known direct activator of adenylyl cyclase that stimulated cAMP production to $2.99 \pm 0.4$ and $8.33 \pm 0.5 \mathrm{nmol} / \mathrm{mg}$ protein, respectively $(P<0.0001, n=4)$. Fig. 6 shows the expected exendin-(9-39) blockade of this response. The specific antagonist inhibited GLP-1-stimulated cAMP production in a concentration-dependent manner with a significant effect of dose vs. response $[\mathrm{F}(3,54)=65.155 ; P<$ $0.0001] .33 \%$ and $87 \%$ reductions of GLP-1-stimulated cAMP production were achieved with $10 \mathrm{nM}$ and $100 \mathrm{nM}$ exendin(9-39), respectively $(P<0.0001, n=4)$. GLP-1 at concentrations up to $5 \mu \mathrm{M}$ had no effect on intracellular $\mathrm{Ca}^{2+}$ in $\mathrm{GT}_{1}-7$ cell suspensions in conditions where clear changes were observed in the presence of $\mathrm{K}^{+}(20 \mathrm{mM})$ or histamine $(100 \mu \mathrm{M}$; results not shown).

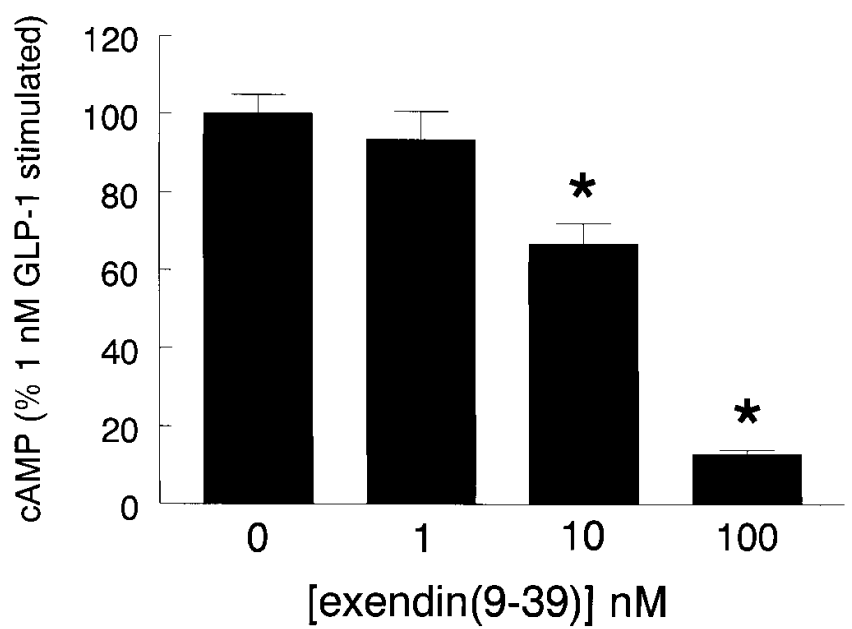

Figure 6. Exendin-(9-39) blockade of GLP-1 stimulated cAMP production in GT1-7 cells. cAMP levels were determined after a 10-min incubation in medium containing $2 \mathrm{mM}$ IBMX plus $1 \mathrm{nM}$ GLP-1 alone or together with increasing concentrations of exendin-(9-39). Results are the mean \pm SE of four experiments performed in quadruplicate and expressed as a percentage of GLP-1 induced cAMP stimulation. Inhibition is concentration-dependent $[\mathrm{F}(3,54)=65.16, P<$ $0.0001]$. [ ${ }^{*} P 0.0001$ exendin-(9-39) vs. GLP-1 (1 nM)].

Effect of GLP-1 on LHRH release from whole hypothalami. Fig. 7 shows the results of an in vitro study performed to determine whether GLP-1 could stimulate LHRH release from intact male rat hypothalamic tissue. One supraphysiological dose of GLP-1 (1 $\mu \mathrm{M})$ was administered to the hypothalami, and a significant increase in LHRH release was observed when compared with the basal value. Basal production was $0.3 \pm 0.07 \mathrm{fmol} / \mathrm{mg}$ wet $\mathrm{wt} / \mathrm{h}$, and GLP- 1 increased this to $220 \%$ of basal $(0.66 \pm 0.12 \mathrm{fmol} / \mathrm{mg}$ wet wt $/ \mathrm{h} ; P<0.04 ; n=12)$. A K $(56 \mathrm{mM})$ challenge significantly increased LHRH release from the hypothalami to $0.95 \pm 0.2 \mathrm{fmol} / \mathrm{mg}$ wet wt $/ \mathrm{h}(P<0.03 ; n=$



Figure 7. GLP-1 stimulation of basal LHRH release from isolated male rat hypothalami. LHRH levels were measured after a 60 -min static incubation with GLP-1 $(1 \mu \mathrm{M})$, and the viability of the tissue was verified by exposure to $56 \mathrm{mM} \mathrm{KCl}$. ( $* P<0.05$ GLP-1 vs. control; $* * P<0.04 \mathrm{KCl}$ vs. control; $n=12$ ). 


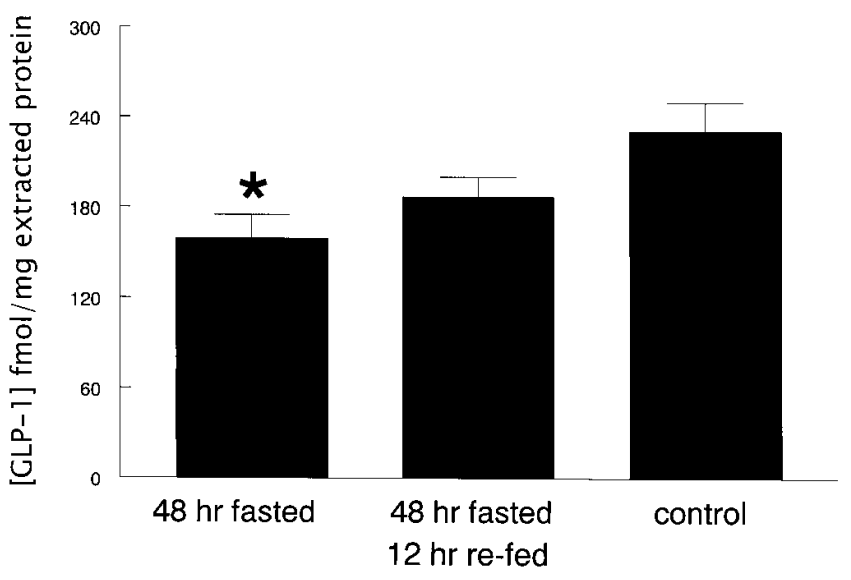

Figure 8. Effect of a 48-h fast and subsequent 12 -h refeeding on hypothalamic GLP-1 content in male rats. Three groups of rats were fasted for $48 \mathrm{~h}$, refed $12 \mathrm{~h}$ after a 48-h fast, or fed ad lib (control). Hypothalamic GLP-1 content was measured by RIA and expressed as fmol per mg extracted protein. ( ${ }^{*} P<0.01$ vs. control; $\left.n=15\right)$.

12), suggesting that the tissue was able to respond to depolarization, and was therefore still viable.

Effect of intracerebroventricular injection of GLP-1 on LH release. The effect of intracerebroventricular injection of GLP-1 on the plasma LH of male rats in pilot studies (data not shown) indicated that GLP-1-stimulated LH release peaked at $5 \mathrm{~min}$. GLP-1 (10 $\mu \mathrm{g}, 3 \mathrm{nmol})$ produced a significant increase in plasma LH levels 5 min after intracerebroventricular administration when compared with saline-injected controls (GLP-1: $1.09 \pm 0.11 \mathrm{ng} / \mathrm{ml}$ vs. saline: $0.69 \pm 0.06 \mathrm{ng} / \mathrm{ml} ; P<0.005)$. In addition, GLP-1 had no effect on plasma follicle-stimulating hormone, thyrotropin, or prolactin levels at this time point (data not shown).

Effect of fasting on GLP-1 content in the rat hypothalamus. Fig. 8 shows the results of a study performed to measure GLP-1 peptide content in male rat hypothalami in different states of fasting. It was clear from the study that nutritional balance appeared to affect hypothalamic GLP-1 levels $[\mathrm{F}(2,42)=5.13 ; P<0.01]$. Hypothalamic GLP-1 levels in control rats that had ad libitum access to food were $230.4 \pm 18.9$ $\mathrm{fmol} / \mathrm{mg}$ extracted protein. After $48 \mathrm{~h}$ of fasting there was a significant decrease in GLP-1 content to $159.1 \pm 15.6 \mathrm{fmol} / \mathrm{mg}$ extracted protein $(P<0.01, n=15)$. 48-h fasting followed by a 12-h refeed resulted in GLP-1 levels of $186.5 \pm 13.3 \mathrm{fmol} / \mathrm{mg}$ extracted protein. Although this group was not significantly different from either the control or the 48-h fasted group, there is indication of a trend that hypothalamic GLP-1 levels are increasing to normal upon refeeding.

\section{Discussion}

The $\mathrm{GT}_{1}-7$ cells exhibit many of the known physiological characteristics of LHRH neurons in situ (30 and references therein); they thus provide a valuable model in which to study the mechanisms controlling release of the hypothalamic peptide. We have shown that GLP-1 causes a concentration-dependent increase in $\mathrm{LHRH}$ release from these cells $\left(\mathrm{ED}_{50}=0.28\right.$ $\mathrm{nM}$ ), and have also demonstrated the presence of specific
GLP-1 binding sites in membrane homogenates. The sites meet the accepted criteria for a ligand-receptor interaction, being time-, temperature-, and protein content-dependent while displaying high affinity, saturability, and specificity. The ligand specificity exhibited by this GLP-1 binding site shows similarities with other GLP-1 receptors; i.e., the exendin peptides (31-33) bind with high affinity, and there is little cross-reactivity with other peptides belonging to the glucagon/ secretin family. Analysis of the binding data identified a single high-affinity binding site $\left(K_{\mathrm{d}}=0.07 \mathrm{nM} ; \mathrm{B}_{\max }=160 \mathrm{fmol} / \mathrm{mg}\right.$ protein) in the $\mathrm{GT}_{1}-7$ cell membranes, a result analogous with that obtained for other GLP-1 binding sites $(8,34,35)$.

To date, GLP-1 receptors in the brain and elsewhere have been shown to mediate an increase in cAMP levels via G-protein-coupled activation of adenylyl cyclase (9). Our results with the $\mathrm{GT}_{1}-7$ cells are consistent with these findings. The threshold concentration of GLP-1 required to produce a significant rise in cAMP formation was equal to the threshold concentration required to significantly stimulate LHRH release from the cells, implying that receptor function is linked with the actions of GLP-1 on cAMP accumulation. In addition, the specific GLP-1 receptor antagonist, exendin-(9-39), inhibited this effect of GLP-1 in a concentration-dependent manner as previously shown in parietal (36) and $\alpha$-TSH cells (19).

GLP-1 did not increase intracellular $\mathrm{Ca}^{2+}$ in $\mathrm{GT}_{1}-7$ cells, even at $5 \mu \mathrm{M}$. This result contrasts with the reports of increased intracellular $\mathrm{Ca}^{2+}$ and activation of phospholipase $\mathrm{C}$ in COS-7 cells transfected with the cloned GLP-1 receptor. This result is unexpected as the $\mathrm{GT}_{1}-7$ cell receptor appears to share very similar properties with the cloned GLP-1 receptor (3739) in other respects such as binding of exendins, antagonistic effects of exendin-(9-39), and activation of adenylyl cyclase. Possible explanations may be that coupling to phospholipase $\mathrm{C}$ is cell-specific, or that overexpression in COS-7 cells led to coupling to G-proteins not normally associated with the GLP-1 receptor, although the high potency of the effect $\left(\mathrm{EC}_{50}=2\right.$ $\mathrm{nM}$ ) would argue against this idea. The lack of effect of GLP-1 on intracellular $\mathrm{Ca}^{2+}$ does not exclude other mechanisms, and we cannot prove categorically from this data that all effects of GLP-1 in these cells are mediated by cAMP.

Evidence presented in this paper leads us to propose that GLP-1 could be a factor involved in control of the hypothalamic-pituitary-gonadal axis. First, our in vitro studies demonstrate a clear ability of the peptide to stimulate release of LHRH both from an immortalized LHRH-secreting cell line $\left(\mathrm{GT}_{1}-7\right.$; reference 22$)$ and from freshly removed rat hypothalamic tissue. We also show that the responses in the cell line are mediated via a specific GLP-1 receptor. Second, we show for the first time that GLP-1 stimulates release of LH in the male rat when injected into the third ventricle. Third, our previous in vitro studies indicate that GLP-1 does not act at the pituitary level to elicit LH release directly (19). Fourth, GLP-1 immunoreactive nerve fibres have been identified throughout the hypothalamus $(4,7,40)$, including the rostral portion that also contains LHRH neurons and axon terminals (41). Moreover, GLP-1 receptor mRNA has been localized in the arcuate nucleus and medial preoptic area $(14,15)$; regions that are rich in LHRH neurons (42). Also of interest in this respect are recent observations demonstrating that female mice with a targeted disruption of the GLP-1 receptor gene exhibit delayed puberty (N.J. Maclusky, J. Kim, L. Scrocchi, and D. Drucker, personal communication). Taken together, these findings sug- 
gest that GLP-1, like several other hypothalamic neuropeptides (43), plays a role as a neuromodulator of reproductive function.

Fertility in mammals requires adequate nutrition and fuel reserves (44). Energy restriction or high energy expenditure results in a failure of the hypothalamo-pituitary-gonadal axis, for example, in eating disorders (anorexia; reference 45), wasting diseases (insulin-dependent diabetes mellitus; reference 46), and high-performance athletes (47). Even short-term changes in food intake can disrupt reproduction in rats (48) and humans (49). A rapid reduction in pituitary LH and gonadal steroid secretion is seen with rapid reinstatement if food consumption is permitted (20). Experimental evidence suggests that the disruption may be in part attributable to perturbations in LHRH secretion (20). The effect of nutritional status on reproduction is thought to reflect the action of metabolic signals that serve as CNS indicators of metabolic state (50). Neuropeptide Y and galanin, for example, are neuropeptides that have been shown to modulate both food intake and the reproductive axis (20). Another potential messenger molecule that may play a role in manifesting reproductive disturbances during periods of energy imbalance is leptin, a hormone secreted from adipose tissue that has been shown to serve as a measure of body adiposity (51). Ob/ob mice are deficient in leptin, and show infertility that can be reversed by administration of leptin $(21,51)$. Furthermore, a recent study showed that leptin stimulated LHRH release from adult male rat hypothalamic explants in vitro and released $\mathrm{LH}$ in female rats in vivo (52).

Studies have defined a role for GLP-1 as a CNS satiety factor $(10,18,53)$. It is possible that this peptide also acts as a messenger molecule between the neural processes that regulate reproduction, and those that maintain energy homeostasis. Perhaps after a short-term negative balance in energy, GLP-1, which is released in the brain after food intake, aids reinstatement of LH secretion. This hypothesis prompted us to investigate GLP-1 levels in the hypothalamus in a state of starvation or negative energy balance that would disrupt the reproductive axis. Indeed, we have shown here that after $48 \mathrm{~h}$ of fasting, rat hypothalamic GLP-1 content is significantly reduced, and upon refeeding a trend to return to normal levels was observed. This finding supports a possible physiological role for GLP-1 as a metabolic signal to the reproductive system. Hypothalamic GLP-1 levels are significantly low in conditions that would result in a rapid reduction in pituitary LH. Upon refeeding, the levels of GLP-1 increase, perhaps aiding reinstatement of LH secretion that has previously been observed (20). The findings presented here imply that GLP-1 may stimulate LH release, at least in part by activating of LHRH neurons. However, the mechanisms of action of this neuropeptide, either alone or in combination with other systems, especially neuropeptide $\mathrm{Y}$ and leptin, are at present not fully understood. It would be of great interest to examine the effect of GLP-1 on the more complex reproductive system of the female rat.

\section{Acknowledgments}

We would particularly wish to thank Professor Pam Mellon for supplying us with the $\mathrm{GT}_{1}-7$ cells. The peptides used in this study were synthesized by Dr. Peter Byfield and Emma Stanton. We are also very grateful to Ms. M. Turton, Dr. M. Rossi, and Mr. S. Abusnana for help with the intracerebroventricular experiments.
S.A. Beak is funded by the British Diabetic Association, M.M. Heath is funded by the Medical Research Council (United Kingdom), and C.J. Small is funded by the Wellcome Foundation.

\section{References}

1. Mojsov, S., G. Heinrich, I.B. Wilson, M. Ravazzola, L. Orci, and J.F. Habener. 1986. Preproglucagon gene expression in pancreas and intestine diversifies at the level of post-translational processing. J. Biol. Chem. 261:1188011889

2. Yoshimoto, S., M. Hirota, C. Ohboshi, and K. Shima. 1989. Identification of glucagon-like peptide-1(7-36) amide in rat brain. Ann. Clin. Biochem. 26: 169-171.

3. Kreymann, B., S. Kanse, M.A. Ghatei, and S.R. Bloom. 1988. Glucagonlike peptide-1 7-36 amide, a new brain-gut hormone and its effect on pancreatic endocrine function in man. Biomed. Res. 9:207-211.

4. Kreymann, B., M.A. Ghatei, P. Burnet, G. Williams, S. Kanse, A.R. Diani, and S.R. Bloom. 1989. Characterization of glucagon-like peptide-1-(736)amide in the hypothalamus. Brain Res. 502:325-331.

5. Kreymann, B., Y. Yiangou, S. Kanse, G. Williams, M.A. Ghatei, and S.R. Bloom. 1988. Isolation and characterization of GLP-1 7-36 amide from rat intestine. Elevated levels in diabetic rats. FEBS Lett. 242:167-170.

6. Jin, S.L., V.K. Han, J.G. Simmons, A.C. Towle, J.M. Lauder, and P.K. Lund. 1988. Distribution of glucagon-like peptide I (GLP-I), glucagon, and glicentin in the rat brain: an immunocytochemical study. J. Comp. Neurol. 271: 519-532.

7. Shimizu, I., M. Hirota, C. Ohboshi, and K. Shima. 1987. Identification and localization of glucagon-like peptide 1 and its receptor in rat brain. Endocrinology. 121:1076-1082.

8. Kanse, S.M., B. Kreymann, M.A. Ghatei, and S.R. Bloom. 1988. Identification and characterization of glucagon-like peptide-1 7-36 amide-binding sites in the rat brain and lung. FEBS Lett. 241:209-212.

9. Fehmann, H.C., B. Goke, and R. Goke. 1995. Cell and molecular biology of the incretin hormones glucagon-like peptide-I and glucose-dependent insulin releasing polypeptide. Endocr. Rev. 16:390-408.

10. Turton, M.D., D. O'Shea, I. Gunn, S.A. Beak, C.M.B. Edwards, K. Meeran, S.J. Choi, G.M. Taylor, M.M. Heath, P.D. Lambert, et al. 1996. A role for glucagon-like peptide-1 in the central regulation of feeding. Nature. 379:69-72.

11. Goke, R., P.J. Larsen, J.D. Mikkelsen, and S.P. Sheikh. 1995. Identification of specific binding sites for glucagon-like peptide- 1 on the posterior lobe of the rat pituitary. Neuroendocrinology. 62:130-134.

12. Calvo, J.C., B. Yusta, F. Mora, and E. Blazquez. 1995. Structural characterization by affinity cross-linking of glucagon-like peptide-1(7-36)amide receptor in rat brain. J. Neurochem. 64:299-306.

13. Thorens, B., A. Porret, L. Buhler, S.P. Deng, P. Morel, and C. Widmann. 1993. Cloning and functional expression of the human islet GLP-1 receptor. Demonstration that exendin-4 is an agonist and exendin- (9-39) an antagonist of the receptor. Diabetes. 42:1678-1682.

14. Alvarez, E., I. Roncero, J.A. Chowen, B. Thorens, and E. Blazquez 1996. Expression of the glucagon-like peptide-1 receptor gene in rat brain. $J$. Neurochem. 66:920-927.

15. Shughrue, P.J., M.V. Lane, and I. Merchenthaler. 1996. Glucagon-like peptide-1 receptor (GLP1-R) mRNA in the rat hypothalamus. Endocrinology. 137:5159-5162.

16. Leibowitz, S.F. 1992. Neurochemical-neuroendocrine systems in the brain controlling macronutrient intake and metabolism. Trends Neurosci. 15: 491-497.

17. Schick, R.R., P. Zimmerman, T. Walde, V. Schusdziarra, and M. Classen. 1992. Glucagon-like peptide (GLP)-1-(7-36)amide: a central suppressor of food intake in fasted rats. Gastroenterology. 102(Abstr.):A756.

18. Tang-Christensen, M., P.J. Larsen, R. Goke, A. Fink-Jensen, D.S. Jessop, M. Moller, and S.P. Sheikh. 1996. Central administration of GLP-1(736)amide inhibits food and water intake in rats. Am. J. Physiol. 271:R848-R856.

19. Beak, S.A., C.J. Small, I. Ilovaiskaia, J.D. Hurley, M.A. Ghatei, S.R. Bloom, and D.M. Smith. 1996. Glucagon-like peptide-1 (GLP-1) releases thyrotropin (TSH): characterization of binding sites for GLP-1 on $\alpha$-TSH cells. Endocrinology. 137:4130-4138.

20. Kalra, S.P., and P.S. Kalra. 1996. Nutritional infertility: the role of the interconnected hypothalamic neuropeptide Y-Galanin-Opioid network. In Frontiers in Neuroendocrinology. W.F. Ganong and L. Martini, editors. Raven Press, Ltd., New York. 371-401.

21. Barash, I.A., C.C. Cheung, D.S. Weigle, H. Ren, E.B. Kabigting, J.L. Kuijper, D.K. Clifton, and R.A. Steiner. 1996. Leptin is a metabolic signal to the reproductive system. Endocrinology. 137:3144-3147.

22. Mellon, P.L., J.J. Windle, P.C. Goldsmith, C.A. Padula, J.L. Roberts, and R.I. Weiner. 1990. Immortalization of hypothalamic GnRH neurons by genetically targeted tumorigenesis. Neuron. 5:1-10.

23. Kreymann, B., G. Williams, M.A. Ghatei, and S.R. Bloom. 1987. Glucagon-like peptide-1 7-36: a physiological incretin in man. Lancet. 2:1300-1304.

24. Gornall, A.G., C.J. Bardawill, and M.M. David. 1949. Determination of serum proteins by means of the biuret reaction. J. Biol. Chem. 177:751. 
25. Bradford, M.M. 1976. A rapid and sensitive method for the quantitation of microgram quantities of protein utilizing the principle of protein-dye binding. Anal. Biochem. 72:248-254.

26. Hunter, W.H., and F.C. Greenwood. 1962. Preparation of Iodine-131 labeled human growth hormone of high specific activity. Nature. 194:495-496.

27. Zamani, M., and D. Bristow. 1996. The histamine H1 receptor in GT1-7 neuronal cells is regulated by calcium influx and $\mathrm{KN}-62$, a putative inhibitor of calcium/calmodulin protein kinase II. Br. J. Pharmacol. 118:1119-1126.

28. Morgan, D.G., P.D. Lambert, D.M. Smith, J.P.H. Wilding, and S.R. Bloom. 1996. Reduced NPY induced feeding in diabetic but not steroid-treated rats: lack of evidence for changes in receptor number or affinity. J. Neuroendocrinol. 8:283-290.

29. Leposavic, G., M. Dashwood, J. Ginsburg, and J.C. Buckingham. 1990. Peripubertal changes in the nature of the GnRH response to alpha-adrenoceptor stimulation in vitro and their modulation by testosterone. Neuroendocrinology. 52:82-89.

30. Besecke, L.M., A.M. Wolfe, M.E. Pierce, J.S. Takahashi, and J.E. Levine. 1994. Neuropeptide Y stimulates luteinizing hormone-releasing hormone release from superfused hypothalamic $\mathrm{GT}_{1}-7$ cells. Endocrinology. 135:16211627.

31. Eng, J., W.A. Kleinman, L. Singh, G. Singh, and J.P. Raufman. 1992. Isolation and characterization of exendin-4, an exendin-3 analogue, from Heloderma suspectum venom. Further evidence for an exendin receptor on dispersed acini from guinea pig pancreas. J. Biol. Chem. 267:7402-7405.

32. Eng, J., and C. Eng. 1992. Exendin-3 and -4 are insulin secretagogues. Regul. Pept. 40:(Abstr.):42.

33. Goke, R., H.C. Fehmann, T. Linn, H. Schmidt, M. Krause, J. Eng, and B. Goke. 1993. Exendin-4 is a high potency agonist and truncated exendin-(9$39)$ - amide an antagonist at the glucagon-like peptide 1-(7-36)-amide receptor of insulin-secreting beta-cells. J. Biol. Chem. 268:19650-19655.

34. Uttenthal, L.O., and E. Blazquez. 1990. Characterization of high-affinity receptors for truncated glucagon-like peptide-1 in rat gastric glands. FEBS Lett. 262:139-141.

35. Goke, R., and J.M. Conlon. 1988. Receptors for glucagon-like peptide1(7-36) amide on rat insulinoma-derived cells. J. Endocrinol. 116:357-362.

36. Schepp, W., J. Schmidtler, T. Riedel, K. Dehne, V. Schusdziarra, J.J. Holst, J. Eng, J.P. Raufman, and M. Classen. 1994. Exendin-4 and exendin-(939)NH2: agonist and antagonist, respectively, at the rat parietal cell receptor for glucagon-like peptide-1-(7-36)NH2. Eur. J. Pharmacol. 269:183-191.

37. Wheeler, M.B., M. Lu, J.S. Dillon, X.H. Leng, C. Chen, and A.E. Boyd III. 1993. Functional expression of the rat glucagon-like peptide-I receptor, evidence for coupling to both adenylyl cyclase and phospholipase-C. Endocrinology. 133:57-62.

38. Widmann, C., E. Burki, W. Dolci, and B. Thorens. 1994. Signal transduction by the cloned glucagon-like peptide-1 receptor: comparison with signal- ing by the endogenous receptors of beta cell lines. Mol.Pharmacol. 45:10291035

39. van Eyll, B., B. Lankat Buttgereit, H.P. Bode, R. Goke, and B. Goke. 1994. Signal transduction of the GLP-1-receptor cloned from a human insulinoma. FEBS Lett. 348:7-13.

40. Larsen, P.J., M. Tang-Christensen, J.J. Holst, and C. Orskov. 1997. Distribution of glucagon-like peptide 1 and other preproglucagon derived peptides in the rat hypothalamus and brainstem. Neuroscience. 77:257-270.

41. Merchenthaler, I., T. Gorcs, G. Setalo, and P. Petrusz. 1984. Gonadotropin-releasing hormone $(\mathrm{GnRH})$ neurons and pathways in the rat brain. Cell Tissue Res. 237:15-29.

42. Kalra, S.P., and W.R. Crowley. 1984. Norepinephrine-like effects of neuropeptide Y on LH release in the rat. Life Sci. 35:1173-1176.

43. Gros, L., B. Thorens, D. Bataille, and A. Kervran. 1993. Glucagon-like peptide-1-(7-36) amide, oxyntomodulin, and glucagon interact with a common receptor in a somatostatin-secreting cell line. Endocrinology. 133:631-638.

44. Van Der Spuy, Z. 1985. Nutrition and reproduction. Clin. Obstet. Gy necol. 12:579-604.

45. Stewart, D. 1992. Reproductive functions in eating disorders. Ann. Med. 24:287-291.

46. Griffin, M., S. South, V. Yankov, R.J. Booth, C. Asplin, J. Veldhuis, and W. Evans. 1994. Insulin-dependent diabetes mellitus and menstrual dysfunction. Ann. Med. 26:331-340.

47. Cumming, D.C. 1993. The effects of exercise and nutrition on menstrual cycle. In Biomedical and Demographic Determinants of Reproduction. R. Gray, H. Leridon, and A. Spira, editors. Clarendon Press, Oxford, United Kingdom.

48. Cameron, J., and C. Nosbish. 1991. Suppression of pulsatile luteinizing hormone and testosterone secretion during short term food restriction in the adult male rhesus monkey (Macaca mulatta). Endocrinology. 128:1532-1540.

49. Cagampang, F., K. Maeda, A. Yokoyama, and K. Ota. 1990. Effect of food deprivation on the pulsatile $\mathrm{LH}$ release in the cycling and ovariectomized female rat. Horm. Metab. Res. 22:269-272.

50. Schreihofer, D., J. Amico, and J. Cameron. 1993. Reversal of fastinginduced suppression of luteinizing hormone $(\mathrm{LH})$ secretion in male rhesus monkeys by intragastric nutrient infusion: evidence for rapid stimulation of LH by nutritional signals. Endocrinology. 132:1890-1897.

51. Chebab, F., M. Lim, and R. Lu. 1996. Correction of the sterility defect in homozygous obese female mice by treatment with the human recombinant leptin. Nat. Genet. 12:318-320.

52. Yu, W.H., M. Kimura, A. Walczewska, S. Karanth, and S.M. McCann. 1997. Role of leptin in hypothalamic-pituitary function. Proc. Natl. Acad. Sci. USA. 94:1023-1028.

53. Lambert, P.D., J.P.H. Wilding, M.A. Ghatei, and S.R. Bloom. 1994. A role for GLP-1(7-36)amide in the central control of feeding behavior. Digestion. 78(Abstr.) 